\title{
Evaluation of Mata Aksara Community Library Program in Increasing People's Reading Interest in Yogyakarta
}

\author{
Nurul Hayati ${ }^{1, *}$ \\ ${ }^{1}$ Department of Non Formal Education, Faculty of Education, Universitas Negeri Padang,Padang, Indonesia
${ }^{*}$ Email: nurul.hayati27@fip.unp.ac.id
}

ABSTRACT

The purpose of this research was to find out program of Community Library, implementation of program and result of implementation Community Library program in increasing reading interest at Mata Aksara Community Library. The type in this research was evaluation research. Evaluation model in this research was using of CIPP model which is developed by Stufflebeam and Gilbert Sax, consist of context, input, process and product. Collecting data use observation technique, interview and documentation. Every data presented was required validity, in obtaining data validity in this research by Triangulation. Result of research showed that evaluation of Mata Aksara Community Library program is good.

Keywords: Community Library, evaluation, reading interest

\section{INTRODUCTION}

In the era of information, one needs to be familiar with the information technology as almost every part of human life have been immensely associated with technology, from work, education, entertainment, and even daily necessities. Everything is related to the outcome of science and information technology. Thus, those who are unable to recognize the importance of acquiring information technology will be foreigner in life.

Nowadays, education is important part in intellectual world event and globalization competition that has been in our country. Qualitty, quantity and realization of human resoruces is a measure of success in education. People get education fully and good curriculum, they can give contribution in reaching educational success. People usually study in school, college, course or education instation to get education.

In order to realize the education, various libraries have built luxurious and sophisticated, reading rooms appear, many e-books in cyberspace. It cannot be reason for not know development of knowledge and world knowledge because convenience to get information can make every knowledge available. Books are available everywhere, libraries in schools and universities. Community Library is also built in some big cities in Indonesia.

Reverse fact prove that Indonesia people's reading interest decrease every year. Based on Badan Pusat Statistik (BPS) in 2003 can be used an illustration how Indonesia people's reading interesrt. The data show that Indonesia people above 15 years old that read newspaper about $55,11 \%$, read magazine or tabloid about $29,22 \%$, read story book about $16,72 \%$, read school textbook about $44.28 \%$ and read other knowledge book about 21,07\% [1].

However, there are some Community Library have achievement in national part. One of them is Mata Aksara Community Library. This Community Library has changed name to be Rumah Pintar Mata Aksara. Achievement that has been achieved by Rumah Pintar Mata Aksara is appreciation from Kementrian Pendidikan dan Kebudayaan as "Community Library Kreatif dan Rekreatif'.

Activities in Mata Aksara Community Library are motorbike around, literacy of reading materials, book practice and other training. Motorbike around is held almost every week. Motorbike around visits crowd place, like tourist place, city center or shopping center and other plcae that often hold event. Activities of literacy of reading materials are borrowing book by members or participants of Community Library, and people read book at the place. Mata Aksara Community Library has ineteresting place to read book, for example tree house and reading room is designed interesting. Reading materials in Mata Aksara Community Library have quite a variety of types, like light reading materials for example fairy tales, and skill reading materials. Skill reading materials usually are practiced in Community Library are cocktail making, skill making from flannel, bag making, organic fertilizer making and others. This Community Library also often held trainings which is related with books, like training of writing biograhphy and others.

Based on these things, researcher want to know how the evaluation of Community Library program in increasing people's reading interest in Yogyakarta. This program evaluation is seen from planning, implementation and implementation result of Community Library program. The success of program does not ecscape from 
learning that is not part of initial or further and higher education.

system of program. Because of that, researcher want to know and evaluate program of Mata Aksara Community Library.

\section{METHOD}

Non-formal education is consciously organized education is carried out but does not follow strict and strict regulation, non-formal education is in infromal education and formal education [2].

According to Joesoef[3], non-formal education have characteristics:

- Non-formal education is more flexible, it means there is no demands of hard credential conditions for their students., implementation time is adjusted to the opportunities available. In terms ogf goals, non-formal education have large goals and can be spesific as needed. The instructors also do not need strict conditions, except that in the lessons provided they must be more than their students.

- Non-formal education may be more effective and efficient for certain fields.

- Non-formal education is Quick yielding, it means in short time can be used to train worker needed, especially for obtaining skilled workers.

- Non-formal education is very instrumental, it means the education is flexible, easy, inexpensive and can produce short time relatively.

According to Hoppers[4], non-formal education includes para-formal education, popular education, personal development, vocational dan professional training, literacy with skill development and supplementary nonformal education program. So that non-formal education as an alternative development of potential of human resources in hopes can be able to compete in world of work and business competitively.

According to Jarvis[5] limits learning and formal, nonformal and informal education, as follows:

- Formal learning: The development of formal lifelong learning by looking initially at the foundations of the idea and thereafter a number of developments, such as the introduction of continuing professional development, continuiting professional development, continuiting education and recurrent education.

- Non-formal learning: Among the major nonformal education developments has been that known as human resource development but the most significant of all was the development of liberal adult education and, more recently, a branch of this : the education of senior citizents

- Informal learning: has three sub-sections covering, respectively, learning in everyday life, self directed learning and what the British government now calls informal learning (Following the OECD) but which basically all
In line with opinions above can be explained the limits of learning and formal, non-formal and informal education, as follows:

- Formal study: development of official longlife learning by looking at initially grounded ideas and then a number of developments, such as the introduction of professional development, continuing professional development, continuing education and repetitive education.

- Non-formal learning: among the major developments in non-formal education is taht is known as human resources development, but the most important of all is the development of liberal adult education and recently a baranch of this: senior citizens education.

- Informal study: it has three sub-section which include study in daily life, self-study directly and the government British now call it as informal learning (after OECD) but basically all learning is not part of the beginning or more and higher education.

Marzuki[7] say that non-formal education exist not because children that cannot access school. All of children in school age are accommodated in school, they are in school or they have graduated will still need non-formal education becuse social culture and technology change very fast and things they get in school cannot help to solve problem, so that they need new skills that must be fulfilled to adjust with the development.

Community Library is an institution serves needs of people for informaion about knowledge in form of reading material and other library material [8]. Managers of Community Library are people who are trusted or have intention of participating to provide needs of people for information about knowledge and have capabilities and technical skills in implementing Community Library [9].

Hatimah \& Sadri[10] Community Library is an institution that provide reading materials needed by people as place for organizing reading and learning skills. Community Library is place to get information for people, especially sourced from library material. Library material is all types of reading material in various forms of media.

Community Library is institution of cultivation people's reading passion through providing service of reading materials in form of collections of printed and non-printed libraries [11].

According to Kalida[9], there are four assessment of Community Library weakness in Indonesia, as follows: Capacity Building Community Library Community Library should be an institution that stands independently, unique and does not depend on government institution. Managing Community Library generally is managed by government officials or office staff. Managing Community Library is not only side job but it is demanded creative, volunteer and high commitment.

Networking Community Library 
Networking Community Library or establish cooperation with other parties is needed for the sustainability of Community Library program in accordance with the expected goals. But, generally Community Library in Indonesia have minimal cooperation partners so that there are many problems in Community Library.

Fundraising Community Library

Fundraising Community Library is an effort to gather sympathy to raise funds and procurement books. In other words, fundraising is process influencing people invidually and institution to share funds to Community Library, but Community Library still depends on old culture of askng, depending, and hanging on to the government.

Publishing Community Library

Publishing Community Library is an effort to publish Community Library or socialization Community Library to people so that people can know existence, benefits and functions of Community Library. But there are still many Community Library managers who do not socialize the existence of Community Library.

According to Yusuf[12], inerest is pleasure or continuous attention to an object because of the expectation of obtaining its benefits. From this understanding, it can be seen that interest is a motivator or strong urge from within a person to carry out a certain activity. Interest can be interpreted as a positive attitude that will be done [13]. According to Juel[14], reading is process in knowing letter and combine word meaning in sentence and reading structure. Sinambela interpreted reading interest positive attitude and there is sense of interest in children about reading activities and are interested in reading books

From the understanding of experts above, it can be concluded that reading interest is a positive attitude to do reading activity without coercion from other people. This reading interest needs coaching and development so the goal can be achieved. Reading interest coaching have to do periodically and continously take place effectively. Community Library plays an important role in conducting reading interest coaching so that it continues to increase. This is certainly done creatively and innovatively so that reading acticity are not something bored fro people.

\section{RESEARCH METHODOLOGY}

Kind of this research is categorized as evaluation research [15]. Evaluation research is research activity to collect data and present accurate and objective information which happen in field about Taman Bacaam Masyarakat program. Evaluation research is to find out accurate information, in this case is evaluation of Mata Aksara Community Library in increasing people's reading interest in Yogyakarta.

Evaluation model which is used in this research is using model CIPP is developed by Stufflebeam[16], consist of context, input, process and product.

Subjects in this research are manager, facilitator and two people who study in Mata Aksara Community Library. Type and data source which is used is primary data and secondary data. Primary data is obtained from manager and program instructor, secondary data is obtained from documentation in Community Library. Collecting data uses observation technique, interview and documentation. Every data presented is required validity, in obtaining validity, it uses Trianggulasi. Trianggulasi is collecting data from various comparison sources. Trianggulasi which is used is trianggulasi source.

\section{RESEARCH AND DISCUSSION}

Evaluation of Mata Aksara Community Library Program

\begin{tabular}{|c|c|c|c|}
\hline Component & Condition in field & Standard & Assessment \\
\hline \begin{tabular}{|l|}
\multicolumn{1}{|c|}{ Contexts } \\
Having \\
program \\
suitability with \\
peopleneeds
\end{tabular} & $\begin{array}{l}\begin{array}{c}\text { Exist, } \\
\text { Community Lata }\end{array} \\
\text { Library } \\
\text { various activara } \\
\text { makes } \\
\text { people needs }\end{array}$ & $\begin{array}{l}\text { Right on target according to the } \\
\text { needs of visitors }\end{array}$ & Appropriate \\
\hline \begin{tabular}{|l|}
\multicolumn{1}{|c|}{ Formulating } \\
objectives of \\
Community \\
Library program
\end{tabular} & $\begin{array}{l}\text { Formulating objectives of } \\
\text { program with managers }\end{array}$ & $\begin{array}{c}\text { Formulating objectives of } \\
\text { program by involving people }\end{array}$ & \begin{tabular}{|c|} 
Not \\
appropriate
\end{tabular} \\
\hline \multicolumn{4}{|l|}{ Input } \\
\hline $\begin{array}{l}\text { Characteristics } \\
\text { of participants }\end{array}$ & Having different background & Involving all people & Appropriate \\
\hline $\begin{array}{c}\text { Characteristics } \\
\text { of managers }\end{array}$ & Friendly service & $\begin{array}{l}\text { All managers have a guard soul } \\
\text { and friendly }\end{array}$ & Appropriate \\
\hline Funding & $\begin{array}{l}\begin{array}{l}\text { Having independent funding } \\
\text { source and government } \\
\text { assistance }\end{array} \\
\end{array}$ & Able to manage funding well & Appropriate \\
\hline $\begin{array}{c}\text { Facilities and } \\
\text { infrastructures }\end{array}$ & $\begin{array}{l}\text { Complete, diverse reading } \\
\text { materials and have skill tools }\end{array}$ & $\begin{array}{l}\text { Diverse reading materials, } \\
\text { activity supporting tools are } \\
\text { available, skill toold are avail able, } \\
\text { administration tools are available }\end{array}$ & Appropriate \\
\hline $\begin{array}{c}\text { Learning } \\
\text { environment } \\
\text { Proces }\end{array}$ & $\begin{array}{l}\text { Comfortable, spacious and } \\
\text { familiar }\end{array}$ & $\begin{array}{cc}\text { Creating } & \text { comfortablr } \\
\text { environment } & \end{array}$ & Appropriate \\
\hline Schedule & 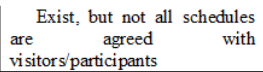 & $\begin{array}{l}\text { Adjusting } \\
\text { schedules }\end{array}$ & Enough \\
\hline $\begin{array}{l}\text { Participants } \\
\text { activity }\end{array}$ & $\begin{array}{l}\text { Most participants are active } \\
\text { and are able to take part in } \\
\text { activities by utilizing facilities } \\
\text { and infrastructure }\end{array}$ & $\begin{array}{l}\text { Participants are active and able } \\
\text { to take part in activities and utilize } \\
\text { the facilities and infrastrucutures } \\
\text { of activities well }\end{array}$ & Good \\
\hline $\begin{array}{l}\text { Managers } \\
\text { activity }\end{array}$ & $\begin{array}{l}\text { Providing material for } \\
\text { activity equipment, filling in } \\
\text { adminitrative supplies that are } \\
\text { not ready }\end{array}$ & $\begin{array}{l}\text { Providing materials and } \\
\text { equipments for activities, } \\
\text { presenting material clearly, giving } \\
\text { opportunity to visitors/participants } \\
\text { in asking, completing } \\
\text { administrative requirements }\end{array}$ & Good \\
\hline \begin{tabular}{|l|} 
Product \\
Achievement \\
of program \\
objectives
\end{tabular} & $\begin{array}{l}\text { Some participants and } \\
\text { visitors have high reading } \\
\text { interest and ability to practice } \\
\text { their skilss } \\
\text { Visitors per day at usual } 3-10\end{array}$ & $\begin{array}{l}\text { Growing people's reading } \\
\text { interest and empowering people } \\
\text { independently } \\
\text { There are } 20 \text { visitors every day }\end{array}$ & Good \\
\hline $\begin{array}{l}\text { Completed } \\
\text { needs }\end{array}$ & $\begin{array}{c}\text { Have had various reading } \\
\text { material }\end{array}$ & $\begin{array}{ccc}\begin{array}{c}\text { Having } \\
\text { material }\end{array} & \text { various } & \text { reading }\end{array}$ & Appropriate \\
\hline $\begin{array}{r}\text { Ability } \\
\text { possessed }\end{array}$ & $\begin{array}{l}\text { Some participants and } \\
\text { visitors are able to practice skills } \\
\text { and take part in reading hobby } \\
\text { activities }\end{array}$ & $\begin{array}{l}\text { Able to practice skilss sourced } \\
\text { from reading material and able to } \\
\text { participate in reading interest } \\
\text { activities }\end{array}$ & Good \\
\hline \begin{tabular}{l}
\multicolumn{1}{c|}{ Community } \\
Library's \\
achievement
\end{tabular} & $\begin{array}{l}\text { Have many achievements in } \\
\text { individual participants, } \\
\text { managers, even Community } \\
\text { Library program itself }\end{array}$ & $\begin{array}{l}\text { Have local and national } \\
\text { achievement }\end{array}$ & priate \\
\hline
\end{tabular}

From table above, evaluation of Mata Aksara Community Library program can be seen that ascpect of context which include relevance program to needs of people are appropriate. While, the formulation of program objectives has not involved people, this considers the way of people; thinking with management of Community Library. It can be seen from aspect of input consist of participants characteristics, managers characteristics, funding, facilities and infrastructures, and learning environment which is 


\section{REFERENCES}

It is proven by various background of participants or visitors of Community Library, complete and adequate facilities and infrastructures, and comfortable learning environment so that particpants or visitors are happy in Mata Aksara Community Library.

It can be seen from aspect of process, adjustment activity schedule sith people's activity is categorized enough. It is proven by some activity schedules are dseigned by managers Community Library. Participants and managers activity can be said good. Because participants and managers are active in joining activity. It can be seen from aspect of product consist of achievement of program objectives, ability possessed, achievement are categorized good. It is proven by program objectives that have achieved, participants have produced skill product and achievements that have achieved by institution and achievements that have achieved by individual. People needs in reading part has been fulfilled. It is because of various reading materials which are owned by Mata Aksara Community Library.

\section{CONCLUSIONS AND SUGGESTIONS}

After researcher did evalution of success of Mata Aksara Community Library program, it can be seen that planning of Mata Aksara Community Library program includes, (1) introduction and preservation of culture, (2) creative program, (3) parenting program, (4) activity program at partner scholl, (5) program of reading fond, (6) life skills education program, (7) plantation amd fertilizer activity, and (8) seminar, talkshow, training. Implementation of Community Library activity program in Mata Aksara Community Library in terms of context which covers needs and objectives program. The result shows that Community Library activity program have suitability with people needs. In terms of input, it consists of participants characteristics, managers characteristics, funding, facilities and infrastructures and learning environment are concluded good. In terms of process, it consists of shcedule, participants activity and managers activity are concluded good. In terms of product, it consists of objectives achievement, completed needs, ability possessed, achievments are concluded good, participants of Community Library get needs that they want and have ability in writing and practice their skill.

Based on observations, discussions and conclusions of research taht focuses on evaluation of success of Mata Aksara Community Library program success in increasing people's reading interest, then the suggetsions are:

Managers and executors of Mata Aksara Community Library should be more creative in creating various activities in increasing people's reading interest.

Management of Mata Aksara Community Library should establish cooperation with other parties so that it creates strong synergy in teaching people.
[1] E. Saepudin, "Tingkat Budaya Membaca Masyarakat," J. Kaji. Inf. Perpust., vol. 3, no. 2, pp. 271282, 2015.

[2] J. Soelaiman, Konsep Dasar Pendidikan Luar Sekolah. Jakarta: PT. Bumi Aksara, 2004.

[3] S. Joesoef, Konsep Dasar Pendidikan Luar Sekolah. Surabaya: Bumi Aksara, 2004.

[4] Y. Suryono and E. Tohani, Inovasi Pendidikan Nonformal. Yogyakarta: Graha cendekia, 2016.

[5] P. Jarvis, Adult Education and Lifelong Learning. New York: Routledge- Falmer, 2004.

[6] S. Marzuki, Pendidikan Nonformal Dimensi dalam Keaksaraan Fungsional, Pelatihan, dan Andragogi. Bandung: Remaja Rosdakarya, 2012.

[7] S. Marzuki, Pendidikan Nonformal: Dimensi dalam Keaksaraan Fungsional, Pelatihan dan Andragogi. Bandung: PT. Remaja Rosdakarya, 2012.

[8] O. C. Jene, "Peran Taman Bacaan Masyarakat dalam Menumbuhkan Budaya Baca Anak di Taman Bacaan Masyarakat 'Mortir' Banyumanik-Semarang," $J$. ILMU Perpust., vol. 2, no. 2, pp. 1-10, 2013.

[9] M. Kalida, Fundraising Taman Bacaan Masyarakat, 4th ed. Yogyakarta: cakruk publishing, 2012.

[10] I. Hatimah and Sadri, Pembelajaran Berwawasan Kemasyarakatan. Jakarta: Universitas Terbuka, 2008.

[11] Kementrian Pendidikan dan Kebudayaan, Petunjuk Teknis Pengajuan, Penyaluran, dan Pengelolaan Bantuan Taman Bacaan Masyarakat Rintisan. Jakarta: Direktorat Jendral PAUD dan Direktorat Pendidikan Masyarakat, 2013.

[12] P. M. Yusuf, Pedoman Penyelenggaraan Perpustakaan Sekolah. Jakarta: Kencana Prenada Media Goup, 2005.

[13] U. Sudarsana, Pembinaan Minat Baca. Jakarta: Universitas Terbuka, 2010.

[14] S. Sandjaja, "Pengaruh Keterlibatan Orang Tua Terhadap Minat Membaca Anak Ditinjau Dari Pendekatan Stres Lingkungan," in Jurnal Psikodimensia, 2001.

[15] S. Arikunto, Manajemen Penelitian. Jakarta: Rineka Cipta, 2002.

[16] D. L. Stufflebeam, Evaluation: Theory, Models and Application. San Fransisco: CA.Whiley, 2007. 